\section{Morgan's crisis}

\section{D. Darlington}

Thomas Hunt Morgan: The Man and His Science. By G. E. Allen. Pp. 447. (Princeton University Press: Princeton, New Jersey, and Guildford, UK, 1979.) $\$ 31.50 ; £ 15.80$.

DURING his life the work of Thomas Hunt Morgan was the centre of many disputes. The chief of these concerned the validity of his famous discovery: Were the chromosomes the physical basis of heredity? Others concerned secondary questions: What did the discovery mean? How was it made? And who made it? The first question for long divided the scientific world into battling parties. The others divided only the new believers who in the course of 50 years have taken possession of the battlefield. For them the secondary questions have grown in importance. And for their solution the life of this enigmatic man has become of absorbing interest.

We now have two books on Morgan from outside his scientific circle which help us to answer these questions. One is a concise but accurate and convincing account by Shine and Wrobel (Kentucky University Press, 1976). The other is this larger treatise by Allen. Neither comes to grips with the crucial issues, perhaps because no one can who was not himself in the fray. Before it is too late, therefore, we should recall how those issues came to a crisis as they did for Morgan in the spring of 1910 .
It was the meeting of two apparently conflicting ideas which created this crisis. Both had come from Europe to the United States in the course of Morgan's teaching life. They had been brought by two unconnected missionaries. One of these was E. B. Wilson who had become the head of Morgan's department at Columbia University. The results of his visits to Europe in 1883 and 1892 were concentrated by Wilson into the three editions of his great book, The Cell; a book which cost him the labour, not of one decade (as $\mathrm{Dr}$ Allen supposes), but of a lifetime. It was a book which argued the central position of the chromosomes in heredity and development.

The other missionary was Bateson, whose journey from England was different in period, scope and direction. His Silliman lectures in 1907 had argued the central position of Mendelism in the study of heredity. And they had converted to his view several shrewd critics at Yale and at Harvard, notably East on the plant side and Castle on the animal side.

So two schools, sharply divided, came into being in the United States. Neither seriously converted the other. And neither in the least converted Morgan. Indeed it seemed that 20 years of embryological experiment had left Morgan without any theory of his own and ostentatiously sceptical of everybody else's. He doubted Wilson's chromosomes. He ridiculed Bateson's factors. He confused Darwin's origin of species with his natural selection, which he even condemned as teleological. And (to use Allen's word) he "chastised" Weismann for his errors. $\mathrm{He}$ paid some respect to the mutation theory of de Vries. But when in 1907 Fernandus Payne, his pupil jointly with
Wilson, asked him for a problem he gave him the Lamarckian task of breeding Castle's Drosophila in the dark for 60 generations.

Payne, as he recalled 67 years later, failed to diminish the fly's eyes by two years' life in the dark. But Morgan himself, in the third year, with a hand lens, was able to find something in the light, a mutation, a single male fly with white eyes. The factor responsible proved to be, as it was likely to be, in the unpaired sex chromosome. From this one fly Morgan could therefore with little trouble demonstrate Mendelian segregation, sex-determination by chromosomes, and sex-linkage. Even, if he had thought of it, he could have seen a ratio distorted by natural selection. The progeny of this one fly corrected unmistakably all Morgan's recent mistakes.

In this embarrassing position Morgan quickly wrote a letter to Science. Then on 7 July. 1910. writing from Wood's Hole (although Dr Allen does not seem to know) he sent the much corrected typescript to Bateson at Cambridge, offering to share with him his stocks and the theory they might carry with them. Bateson, however, had come to distrust Morgan's judgement and he evidently declined the stocks; he also certainly rejected the theory.

Having failed to enlist Mendelian support. Morgan, back in New York, turned to the chromosome side, to Wilson in the next room to his own. Wilson was able to tell Morgan about the Belgian cytologist, Janssens, who from seeing chiasmata between chromosomes at meiosis recalled, as German cytologists had done earlier, Weismann's theory of meiosis. This theory demanded recombination which would arise by "crossing over" and would explain linkage. Wilson was also able to recommend to Morgan three pupils who had learnt about the chromosome theory from him, and about Mendelism from the books of Bateson's disciples, Punnett and Lock. They would breed his flies

The results in the fly-room were dramatic. But what exactly happened? The answer I partly discovered for myself when twenty years later I questioned the two leading figures in the drama. Who did it, I asked Wilson; and his reply was quite firm. Morgan's three greatest discoveries, he said, were those three men, Bridges, Sturtevant and Muller. Then I asked Morgan what Janssens' idea had meant for him. s Janssens, Morgan replied, being a $\Sigma$ Jesuit, had seen his problem not scientifically but teleologically. His idea of crossing over must have come from s the belief that there could not always $\checkmark$ be four products of meiosis in all sexual reproduction unless all four were different. Morgan clearly had not read 
Janssens' article. He did not know that in his first sentence Janssens deduced his argument from Weismann, that is, from the belief that only with recombination could natural selection be made to work. I sadly concluded that Morgan had never understood, and perhaps had long made up his mind not to understand, the chromosome side of the chromosome theory.

'The gaps in understanding between Wilson. Morgan and Bateson were profound. How profound is shown by their continuance today, and by the failure of Morgan's biographer to notice them. For this reason he does not realise that the process of crossing-over between chromosomes has never been seen in female Drosophila. He does not realise that it remains, as Morgan would have said before he inferred it, a pure speculation. Nor does Allen realise the fear Morgan had of discussing the other side of the story, the absence of crossing over in the male Drosophila. Was its purpose perhaps to make his experiments possible? We shall never know.

For over 20 years Morgan had demanded facts and denounced speculation. But now, swept forward by the success of his clever young men, he found himself inscribing his name as the head of a grand speculative movement. Dr Allen devotes proper attention to those three young men: Bridges, the quiet easy-going countryman from the north. whose keen eyes discovered hundreds of mutations;
Sturtevant, the observant horse-breeder from the south whose ingenious experiments and interpretations carried him beyond heredity into development; Muller, the intense excitable New York Jew whose imagination went too fast and too far for Morgan's understanding or forbearance.

These men did not create a unified genetic theory. That was too much to expect. But they put together the assembly line of a great Drosophila: industry. Surely no city but New York? at that time could have brought together such a combination of talent. And if Morgan had a "creative genius" as Dr Allen calls it, it was that, when he saw what they could do, he let them do it.

The defect of this Drosophila in 3 dustry lay in the limitations of the fly. It failed to reveal the chromosome processes underlying its heredity and indeed heredity in general. The drosophilists had to avoid meiosis. Making a virtue of necessity, Muller therefore quickly went beyond the chromosome to the gene. There the reluctant Morgan followed him to adopt the gene as his own. The chromosomes could then he taken for granted. Reversing the order of Nature the chromosomes did what the fly required. This was Morgan's "Theory of the Gene".

After the lapse of years Morgan. having lost interest in the expe sments of genetics, and never having sustained an interest in its ideas, was awarded a Nobel Prize. Dr Allen's account allows us a glimpse of the embarrassment that once again overtook him. Having delayed his journey to Stockholm, on his way he arrived in Edinburgh still uncertain what, and whom, and how much, he should acknowledge. Such a failure to sort out his intellectual antecedents might be thought to be a merely personal problem and one not uncommon in science. But in this case, its effects have survived far beyond any personal interests. The hiatus in the relations of Morgan. with Bateson on the one hand, and with Weismann, Boveri, Janssens and Wilson on the other, has left its traces in the dichotomy of genetics as it is taught today, a defect liberally illustrated in the present biography.

The Nobel Prize had been heralded by a last general discourse, a book of lectures unhappily entitled The Scientific Basis of Evolution. In the one original chapter in this work Morgan finds himself trapped with the too obvious notion that the evolution of $\Sigma$ man introduces a new biological $\bar{\Phi}$ principle. In his view there are now "two processes in inheritance" in man. The inheritance of culture, he explains. is now independent of the old limita$\delta$ tions of genetic inheritance as under-

\section{Sorry, for copyright reasons some images on this page may not be available online}

stood, for example, in the fly.

It is surprising that Julian Huxley in a book on evolution which he dedicated to Morgan should have adopted this fallacy of Morgan's 30 years later as his own. Without apparently knowing its source he described it as "psychosocial inheritance". But it is even more surprising that Morgan's biographer, claiming to be a Marxist (who should always know what he is going to discover), has now failed to notice this gem of Marxist dialectic: for here is an idea which opens the way so agreeably to Lamarckism and Lysenkoism. From it the whole froth of our social sciences today, with their specious arguments and calamitous consequences, easily flows and overflows.

Dr Allen must have occupied many years in preparing this work, as his method of assembling it is a recipe for chaos, chaos in writing and chaos in reading. His accommodation of Bateson (and the present reviewer) at the John Innes Horticultural "School" which he places in Merton College, Cambridge. is an extreme example But what can be expected of a writer who buries his references irrecoverably in 743 footnotes dispersed throughout the text? Clearly his book may help later enquirers into the history of genetics. But not unless they are willing to start at the beginning again, however distressing the results of their enquiries may be.

C. D. Darlington is Emeritus Professor of Botany at the University of Oxford, UK. 